\title{
Ryegrass contamination of endophyte-free dairy pastures after spray- drilling in autumn
}

\author{
V.T. VAN VUGHT and E.R. THOM \\ Dairying Research Corporation, Private Bag 3123, Hamilton
}

\begin{abstract}
Ryegrass contamination of endophyte-free ryegrass (Lolium perenne L.) pastures, established by autumn spray-drilling of existing endophyteinfected pasture, was studied over one year at the Dairying Research Corporation, Hamilton. Main plots were sprayed with glyphosate at $1.44 \mathrm{~kg}$ a.i./ ha (4 1/ha of Roundup G2) in mid-March 1996 (S), or mid March and again in mid April (D). White clover (Trifolium repens L.) was removed from half the area of each main plot using herbicide and the remainder was drilled with white clover. All plots were direct drilled with endophyte-free perennial ryegrass in late April. Plots were rotationally grazed by dairy cows. Volunteer perennial ryegrass seedlings that germinated from seed in dung pats, on the soil surface (reseeding) and after recovery from the seed-bank, contained 40, 66 and $69 \%$ endophyte, respectively. The largest inputs of volunteers came from dung and reseeding. The average dung pat covered $0.08 \mathrm{~m}^{2}$ and supported 3 volunteer ryegrass seedlings (range 0 14). After the first spraying 0.87 ryegrass clumps/ $\mathrm{m}^{2}$ were surviving, and $0.13 / \mathrm{m}^{2}$ survived both herbicide applications; half were infected with endophyte. After one year, contamination of $\mathrm{S}$ was 2.5 times higher than D plots (18 vs $7 \%$ of plants endophyte infected), showing that double spraying in autumn was effective at reducing contamination to a low level.
\end{abstract}

Keywords: dairy pastures, dung, endophyte, Lolium perenne, reseeding, seed-bank, seed transfer, volunteer ryegrass

\section{Introduction}

In a previous trial contamination of endophyte-free ryegrass (Lolium perenne L.) pastures with endophyteinfected ryegrass was rapid, reaching $50 \%$ after 3 years (Thom et al. 1997).

The fungal endophyte Neotyphodium lolii produces alkaloids which can cause animal health problems (Gallagher et al. 1981; Easton et al. 1996), but also promotes ryegrass persistence by deterring attack by Argentine stem weevil. New endophytes with reduced levels of the alkaloids affecting animals are being tested, and it will be necessary to devise methods of establishing and maintaining pastures containing these new endophytes free of the wild-type endophyte. For this to occur, the sources of contamination need to be identified.

Hume \& Lyons (1992) studied contamination of "lolitrem-free" perennial ryegrass pasture via natural reseeding of endophyte-infected ryegrass, as influenced by different pre-sowing treatments like hard grazing. However, it was difficult to eliminate reproductive development in ryegrass by management, and therefore natural reseeding (L'Huillier \& Aislabie 1988). Modern perennial ryegrasses continue to produce mature seed over summer (aftermath heading), providing a possible source of endophyte (Latch 1994).

This paper reports on the first year of a 2-year trial investigating the origins of endophyte-infected ryegrass plants in pastures sown with endophyte-free ryegrass. Unlike previous research, it also considers seed in dung as a source of contamination.

\section{Methods}

\section{Trial design and treatments}

At the Dairying Research Corporation, Hamilton, on a Te Kowhai clay loam soil, $20 \times 16 \mathrm{~m}$ main plots were identified in March 1996 in a 0.25 ha paddock containing high endophyte ryegrass (86\% of tillers infected) and white clover. Plots were sprayed once (S) on 11 March 1996 with glyphosate at $1.44 \mathrm{~kg}$ a.i./ha (higher than the recommended rate of $1.08 \mathrm{~kg}$ a.i./ha; no Pulse penetrant was added), equivalent to $41 /$ ha of Roundup G2. This was repeated on half of the plots on 12 April (double sprayed, D). Each plot was equally divided into two sub-plots; one was sprayed on 7 March with dicamba ( $0.6 \mathrm{~kg}$ a.i./ha or $3 \mathrm{l} / \mathrm{ha}$ of product) to kill white clover and the other drilled with Grasslands Kopu white clover $(3 \mathrm{~kg} / \mathrm{ha})$ on 27 April. The trial area was direct-drilled with endophyte-free Yatsyn 1 ryegrass (10 kg/ha single pass) on 26 April 1996. Treatments were replicated 4 times in a randomised block design.

Detailed pasture measurements were confined to 4 fixed frames $(0.6 \times 1.2 \mathrm{~m})$ per sub-plot. These were positioned randomly but stratified to enable study of the effects of dung. Two frames were located on areas where dung had been deposited during grazings over 
summer and autumn (December 1995 to March 1996); the remaining frames were controls (no dung present).

\section{Grazing management}

The plots were rotationally grazed by dairy cows, stocked at 4 cows/ha. During the 3 months before spray-drilling and during the trial, the cows had grazed high-endophyte ryegrass pastures the previous day.

\section{Measurements}

\section{Endophyte}

On 19 August 1996, and 3 February and 10 March 1997, tillers of 20 ryegrass plants per subplot were assessed for endophyte presence (Latch et al. 1984). In mid April 1996 seedlings from 20 dung pats (3-5/pat) in $\mathrm{S}$ plots (excluding those in fixed frames) were selected and assessed for endophyte presence.

\section{Ryegrass survival after spraying}

Fifteen and 31 days after the first spraying, surviving ryegrass clumps and new seedlings were noted in each frame. Survivors were categorised as having at least one green tiller. Seedlings germinating in dung were noted and the size of each selected dung pat measured.

Ryegrass clumps that maintained green tillers after the second spraying were tagged and counted on 3 occasions in May and June, as were volunteer ryegrass seedlings. Surviving ryegrass clumps and volunteer seedlings were removed in June and tested for endophyte presence.

\section{Seedbank sampling}

In April 1996, 20 soil cores ( $5 \mathrm{~cm}$ diameter, $5 \mathrm{~cm}$ depth) were taken at random from each of the 16 sub-plots. Viable ryegrass seed was germinated in a controlled environment (Thompson \& Grime 1979), and seedlings were counted and assessed for endophyte.

\section{Sown and volunteer ryegrass density}

Two $10.4 \mathrm{~cm}$ diameter rings were fixed in random positions in May 1996 on drill rows (sown ryegrass, $\mathrm{SR}$ ) and 2 between drill rows (volunteer ryegrass, VR) in each frame (excluding previously tagged volunteers). All enclosed plants were tagged and their survival and tiller number monitored monthly from May 1996. VR germinating in autumn 1997 was identified with different-coloured tags.

\section{Results}

\section{Climate}

Rainfall was high throughout autumn 1996, with March having $104 \mathrm{~mm}$ compared to $91 \mathrm{~mm}$ for the 10-year average, and April having more than double the 10year average $(85 \mathrm{~mm})$. Winter rainfall was $22 \%$ higher than the 10 -year average $(339 \mathrm{~mm})$, spring was normal $(292 \mathrm{~mm})$ and summer was $64 \%$ of the 10 -year average (270 mm). Rainfall in March 1997 was 79\% higher than the 10-year average $(91 \mathrm{~mm})$ and April was normal. The average maximum air temperature for 1996 was above the 10-year average, but lower for March and April 1997. The average grass minimum temperature for winter was $1.4^{\circ} \mathrm{C}$ with 38 frosts $\left(<-1.0^{\circ} \mathrm{C}\right)$, compared with $1.2^{\circ} \mathrm{C}$ and 56 frosts for the 10 -year average.

\section{Endophyte}

Double spraying markedly reduced contamination of the plots with endophyte-infected ryegrass compared with single spraying (Table 1). Endophyte occurence decreased with time in the single sprayed treatment but not in the double sprayed. Clover treatments had no significant effect on plot endophyte status.

Table 1 Effect of single and double applications of glyphosate on endophyte content (\% of plants infected), approximately 4, 10 and 11 months after sowing.

\begin{tabular}{lccc}
\hline Spray treatment & $\begin{array}{c}\text { August } \\
1996\end{array}$ & $\begin{array}{c}\text { February } \\
1997\end{array}$ & $\begin{array}{c}\text { March } \\
1997\end{array}$ \\
\hline Single & 43 & 28 & 18 \\
Double & 8 & 5 & 7 \\
SED & 3.6 & 2.1 & 3.1 \\
Significance & $* *$ & $* *$ & $*$ \\
\hline
\end{tabular}

\section{Dung}

The average area of selected dung pats was $0.08 \mathrm{~m}^{2}$. By 11 April an average of 3 ryegrass seedlings had germinated in framed dung pats (range 0-14). This equates to an average of 37.5 seedlings $/ \mathrm{m}^{2}$ of dung.

Three weeks after the second application of glyphosate (3 May) there were only 3.1 ryegrass seedlings $/ \mathrm{m}^{2}$ of dung, $75 \%$ of these in $\mathrm{S}$ plots, although by this time it was difficult to define dung in most frames after disturbance by drilling and rain.

Of the 95 ryegrass seedlings selected from 20 nonframed dung pats (3-5 seedlings/dung pat), $40 \%$ contained endophyte. Five of the dung pats sampled had endophyte-free ryegrass, and the remainder had at least one seedling that contained endophyte.

\section{Appearance and survival of volunteer ryegrass seedlings in fixed frames}

Two weeks after the first spraying, no ryegrass seedlings had germinated (Table 2). By 11 April, however, 2.0 and 2.2 seedlings $/ \mathrm{m}^{2}$ had germinated in $\mathrm{S}$ and D plots, respectively. 
Three weeks after the second spraying ryegrass seedlings in $\mathrm{S}$ plots had more than doubled to $4.6 / \mathrm{m}^{2}$, and the number in D had declined sharply to $0.35 /$ per $\mathrm{m}^{2}$ (Table 2). Seedling numbers were always higher in dung-affected frames than in controls for both $\mathrm{S}$ and $\mathrm{D}$ plots. There was little change in the number of volunteer ryegrass seedlings over May and until their removal for endophyte sampling in early June. On testing 68 of these seedlings, $66 \%$ contained endophyte.

\section{Ryegrass clumps}

Ryegrass survival was variable following the first spraying and ranged from 0.61 to 1.39 clumps $/ \mathrm{m}^{2}$ by 11 April. After the second spraying survivors declined in both treatments and averaged 0.57 and 0.13 clumps/ $\mathrm{m}^{2}$ for $\mathrm{S}$ and $\mathrm{D}$, respectively (Table 3). Because of the arrangement of frames, some of the ryegrass clumps in single-sprayed dung-affected frames may have been killed by drift from the second spraying (12 April). The clumps that survived double spraying were in dung-affected frames. Fifty per cent of the clumps still surviving in June contained endophyte.

\section{Seed-bank}

Ryegrass seed germinated in soil from 8 of the 16 subplots, 6 of which produced only one seedling. A total of 16 ryegrass plants germinated and 11 contained endophyte.

\section{Sown plants in fixed rings}

D plots consistently had more sown plants than $S$, but reached significance $(\mathrm{P}<0.05)$ only in April 1997. Sown plant density was also consistently higher in the dung-affected than control plots and was close to significance $(\mathrm{P}<0.09)$ only in May and July 1996 (Figure 1).

\section{Volunteer ryegrass plants in fixed rings}

Statistical analysis of volunteer plant data was not possible, as volunteers did not appear in many plots from June 1996 to April 1997.

S plots contained more volunteers than D (Table 4), because D control plots contained no volunteers until autumn 1997, and the number appearing in dung-affected
Table 2 Effect of single (March) and double (March, April) applications of glyphosate in 1996 on appearance and survival of volunteer ryegrass seedlings $/ \mathrm{m}^{2}$ in control frames and those surrounding dung pats.

\begin{tabular}{|c|c|c|c|c|c|c|}
\hline Date & Control & $\begin{array}{l}\text { Single } \\
\text { Dung c }\end{array}$ & Average & Control & $\begin{array}{l}\text { Double } \\
\text { Dung }{ }^{c}\end{array}$ & Average \\
\hline $26 \operatorname{March}(15)^{\mathrm{a}}$ & 0.00 & 0.00 & 0.00 & 0.00 & 0.00 & 0.00 \\
\hline 11 April $(31)^{a}$ & 2.60 & 1.39 & 2.00 & 2.60 & 1.82 & 2.21 \\
\hline 3 May $\left(51^{a}, 21^{b}\right)$ & 2.86 & 6.42 & 4.64 & 0.26 & 0.43 & 0.35 \\
\hline 21 May $(69,39)$ & 2.78 & 6.34 & 4.56 & 0.26 & 0.43 & 0.35 \\
\hline 6 June $(85,55)$ & 2.52 & 6.16 & 4.34 & 0.17 & 0.34 & 0.26 \\
\hline $\begin{array}{ll}\text { a } & \text { Days from first } \\
\text { b } & \text { Days from secc } \\
\text { c } & \text { Excludes seedl }\end{array}$ & $\begin{array}{l}\text { praying } \\
\text { d spraying } \\
\text { gs germin }\end{array}$ & ating in & enclos & ung pats & & \\
\hline
\end{tabular}

Table 3 Effect of single (March) and double (March, April) applications of glyphosate and survival of existing ryegrass clumps $/ \mathrm{m}^{2}$ in control frames and those surrounding dung pats.

\begin{tabular}{|c|c|c|c|c|c|c|}
\hline Date & Control & $\begin{array}{c}\text { Single } \\
\text { Dung }\end{array}$ & Average & Control & $\begin{array}{l}\text { Double } \\
\text { Dung }\end{array}$ & -------- \\
\hline $26 \operatorname{March}(15)^{\mathrm{a}}$ & 0.52 & 1.56 & 1.04 & 0.43 & 0.52 & 0.48 \\
\hline 11 April (31) ${ }^{a}$ & 0.78 & 1.39 & 1.09 & 0.61 & 0.69 & 0.65 \\
\hline 3 May $\left(51^{a}, 21^{b}\right)$ & 0.61 & 0.61 & 0.61 & 0.00 & 0.26 & 0.13 \\
\hline 21 May $(69,39)$ & 0.52 & 0.61 & 0.57 & 0.00 & 0.26 & 0.13 \\
\hline 6 June $(85,55)$ & 0.52 & 0.61 & 0.57 & 0.00 & 0.26 & 0.13 \\
\hline \multicolumn{7}{|c|}{ Days from first spraying } \\
\hline \multicolumn{7}{|c|}{ Days from second spraying } \\
\hline
\end{tabular}

Figure 1 Effect of dung and single and double applications of glyphosate on sown plant density from May 1996 to April 1997.

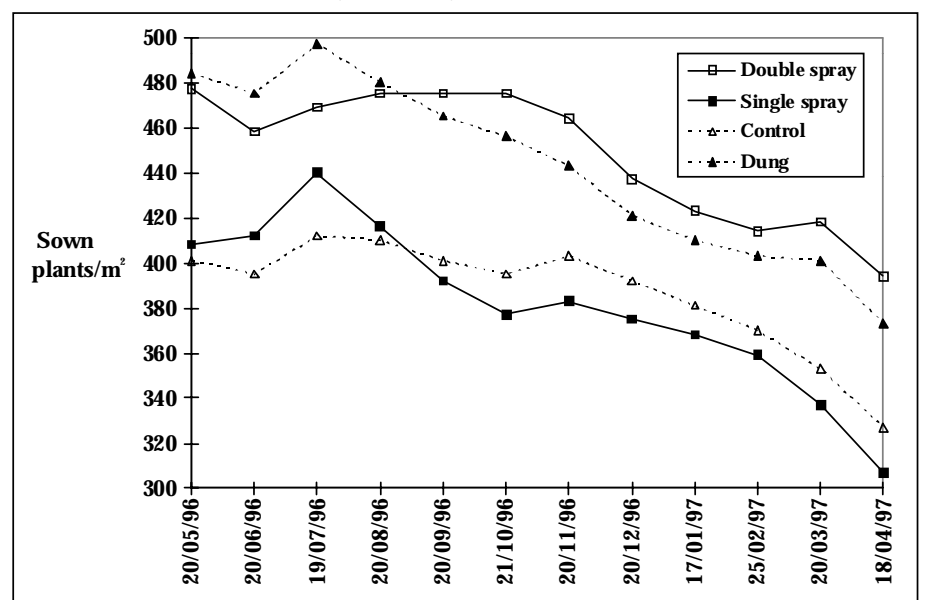

plots was less in D than S. The most volunteer plants appeared in dung-affected $\mathrm{S}$ areas, and these more than tripled in autumn 1997. 
Table 4 Effect of dung and single and double applications of glyphosate on volunteer plant density (plants $/ \mathrm{m}^{2}$ ) from June 1996 to April 1997.

\begin{tabular}{lcccc}
\hline Treatment & Winter & Spring & Summer & Autumn \\
\hline Double - Control & 0 & 0 & 0 & 18 \\
Double - Dung & 4 & 7 & 6 & 9 \\
Single - Control & 7 & 11 & 8 & 9 \\
Single - Dung & 9 & 21 & 20 & 77 \\
\hline
\end{tabular}

\section{Discussion}

This trial has shown that contamination of endophytefree ryegrass with endophyte-infected ryegrass can come from diverse sources, when an existing endophyteinfected pasture was spray-drilled. These included ryegrass seed in cow dung, germination of ryegrass seed that matured in the current season (natural reseeding), survival of existing endophyte-infected ryegrass or buried seed.

\section{Dung effects}

Pasture seeds can pass unharmed through animals and then germinate in dung (e.g., Watkin \& Clements 1978). This is the first New Zealand report of the endophyte in such seed also remaining viable. Although the practical impact of this finding is difficult to quantify, Wolton (1979) concluded that for highly stocked cows (4 cows/ha), the total pasture area covered by dung from one cow per grazing ranged from 0.45 to $1.1 \mathrm{~m}^{2}$.

We assume mature seed-heads were eaten by the cows during summer grazings, because aftermath heading was a feature of the ryegrasses on the dairy. All dung pats evaluated were covered with a hard crust, suggesting they were deposited during sunny weather (Weeda 1967), probably in January or February. At each grazing of the trial paddock a stocking rate of 160 cows/ha was used; the above suggests a total dung pat area of 72 to $176 \mathrm{~m}^{2} /$ ha per grazing. With an average of 3 ryegrass seedlings per $0.08 \mathrm{~m}^{2}$ dung pat, an average input per grazing of 4712 seeds/ha of which $40 \%$ or 1885 contained endophyte, could be possible on dairy farms in this region.

\section{Volunteer ryegrass seedlings}

The first spraying in March 1996 killed existing VR seedlings (Table 2). During late April, establishment of new VR seedlings was greater in dung-affected S plots than in controls, possibly because of extra nutrient supply from the dung (Marsh \& Campling 1970), reaching a peak in early May. Appearance of new VR seedlings following the second spraying in April was much reduced (Table 2), and this large difference probably contributed to the reduced endophyte contamination in double compared with single-sprayed plots (Table 1), since $66 \%$ contained endophyte.

Continued monitoring of VR seedling appearance in fixed rings showed double spraying maintained volunteers at a low level until the following autumn compared with spraying once, (Table 4), when presumably some of the ryegrass seed maturing in the previous summer germinated (L'Huillier \& Aislabie 1988). Hume \& Lyons (1992) recommended managements such as cropping and hard grazing to minimise the effect of reseeding on contamination levels.

\section{Survival of existing ryegrass}

Some of the existing ryegrass clumps survived the herbicide applications. Survival of ryegrass clumps after the first spraying (Table 3) was possibly aided by lack of penetration and plant uptake since the pasture was long $(15-20 \mathrm{~cm})$ and no extra penetrant was added. The presence of dung may also prevent herbicide uptake by some plants (Table 3), since more clumps survived in dung affected than control frames after the first spray, and again after the second spraying.

\section{Influence of seed-bank}

Seed-bank sampling revealed a low level (16) of viable ryegrass seeds, confirming the finding of Hume \& Lyons (1992). This result was expected since ryegrass seed has no dormancy mechanism (Thompson \& Grime 1979) and does not build up in the soil seed-bank. Even though $69 \%$ of the plants identified contained endophyte, this source is unlikely to greatly affect the overall endophyte level of the pasture.

\section{Plot endophyte levels}

Contamination levels after one year (Table 1) were similar to those recorded in March 1994 (23-30\%) at the equivalent stage of an earlier trial on the same dairy (Thom et al. 1997). There was an unexplained decline in endophyte contamination with time (Table 1) to which sampling errors could have contributed.

\section{Conclusions}

Autumn spray-drilling has been accepted by farmers as a successful method of renovating dairy pastures. This work shows considerable germination of volunteer ryegrass seed was possible after autumn spraying with herbicide. The main sources of volunteer ryegrass were seeds in dung and those germinating on the soil surface; seed from both sources contained viable endophyte.

Our findings have important implications for the success of new endophytes that will maintain insect protection without animal health problems. Some 
farmers renovate up to $20 \%$ of their farm each year, so sources of wild (less desirable) endophyte will remain. This trial shows double spraying in autumn is an effective way of reducing contamination. Managements to reduce number and ripening of ryegrass seed-heads will lessen transport by cows and the impact of autumn natural reseeding.

\section{ACKNOWLEDGEMENTS}

Sergio Marshall (AgResearch, Ruakura) for endophyte screening; Roslyn McCabe, Deanne Waugh and Helen Simons for technical assistance; Pat Laboyrie for grazing management; Rhonda Hooper for the statistical analysis; and the Foundation for Research, Science and Technology for research funding.

\section{REFERENCES}

Easton, H.S.; Lane, G.A.; Tapper, B.A.; Keogh, R.R.; Cooper, B.M.; Blackwell, M.; Anderson, M.; Fletcher, L.R. 1996. Ryegrass endophyte-related heat stress in cattle. Proceedings of the New Zealand Grassland Association 57: 37-41.

Gallagher, R.T,; White, E.P.; Mortimer, P.H. 1981. Ryegrass staggers; isolation of potent neurotoxins lolitrem A and lolitrem B from staggers producing pastures. New Zealand veterinary journal 29: 189190.

Hume, D.E.; Lyons, T.B. 1992. Establishment of new pastures free of ryegrass contamination. Proceedings of the New Zealand Grassland Association 54: 151156.
Latch, G.C.M. 1994. Influence of Acremonium endophytes on perennial grass improvement. New Zealand journal of agricultural research 37: 311-318.

Latch, G.C.M.; Christensen, M.J.; Samuels, G.J. 1984. Five endophytes of Lolium and Festuca in New Zealand. Mycotaxon 20: 525-550.

L'Huillier, P.J.; Aislabie, D.W. 1988. Natural reseeding in perennial ryegrass-white clover dairy pastures. Proceedings of the New Zealand Grassland Association 49: 111-115.

Marsh, R.; Campling, R.C. 1970. Fouling of pastures by dung. Herbage abstracts 40: 123-130.

Thom, E.R.; Clark, D.A.; Waugh, C.D.; McCabe, R.J.; van Vught, V.T.; Koch, B.J.L. 1997. The effect of ryegrass endophyte on milk production from dairy cows in northern New Zealand. Proceedings of the 18th International Grassland Congress Vol 1: Section $1,11-15$.

Thompson, K.; Grime, J.P. 1979. Seasonal variation in the seedbanks of herbaceous species in ten contrasting habitats. Journal of ecology 67: 893921.

Watkin, B.R.; Clements, R.J. 1978. The effects of grazing animals on pastures. pp. 273-289 In Plant relations in pastures, Wilson, J.R.(ed.). CSIRO.

Weeda, W.C. 1967. Effects of cattle dung patches on pasture growth, botanical composition and pasture utilization. New Zealand journal of agricultural research 10: 150-159.

Wolton, K.M. 1979. Dung and urine as agents of sward change: a review. pp. 131-135. In Occasional Symposium No. 10, Charles, A.H.; Hagger, R.J.(eds.). British Grassland Society. 
